\title{
ANALISIS KESESUAIAN LAHAN UNTUK PENGEMBANGAN BUDIDAYA RUMPUT LAUT DI GUSUNG BATUA, PULAU BADI KABUPATEN PANGKEP, SULAWESI SELATAN
}

\author{
Petrus Rani Pong-Masak", Andi Indra Jaya Asaad", Hasnawi", \\ Andi Marsambuana Pirzan"), dan Mahatma Lanuru*) \\ *) Balai Riset Perikanan Budidaya Air Payau \\ Jl. Makmur Dg. Sitakka No. 129, Maros 90512, Sulawesi Selatan \\ E-mail:pg_masak@yahoo.com \\ *) Fakultas IImu Kelautan dan Perikanan, Universitas Hasanuddin \\ Jl. Perintis Kemerdekaan, km. 10, Makassar, Sulawesi Selatan
}

(Naskah diterima: 27 April 2009; Disetujui publikasi: 29 April 2010)

\begin{abstract}
ABSTRAK
Budidaya rumput laut sangat prospektif menjadi alternatif usaha oleh masyarakat pesisir dan pulau-pulau kecil. Pemilihan lokasi budidaya melalui kegiatan inventarisasi dan pemetaan potensi sumberdaya lahan merupakan tahapan awal yang penting dilakukan. Penelitian ini bertujuan menentukan kelayakan lahan perairan untuk pengembangan budidaya rumput laut di Gusung Batua, Pulau Badi Kabupaten Pangkep. Penelitian dilakukan dengan metode survai untuk mendapatkan data primer dengan pendekatan SIG dan data sekunder. Data dianalisis dengan metode PATTERN berdasarkan skoring dari beberapa variabel kunci untuk menentukan tingkat kelayakan lahan bagi pengembangan budidaya rumput laut. Hasil penelitian menunjukkan bahwa perairan Gusung Batua di Pulau Badi memiliki potensi lahan pengembangan budidaya rumput laut dengan tingkat kelayakan tinggi seluas 42,1 ha $(4,2 \%)$, tingkat kelayakan sedang 660,3 ha $(66,6 \%)$, dan tingkat kelayakan rendah 156,8 ha $(15,8 \%)$.
\end{abstract}

KATA KUNCI: lahan budidaya, rumput laut, gusung, Kabupaten Pangkep

ABSTRACT: Analysis of waters suitable for development of seaweed culture in Batua Reef, Badi Island Pangkep Regency, South Sulawesi. By: Petrus Rani Pong-Masak, Andi Indra Jaya Asaad, Hasnawi, Andi Marsambuana Pirzan, and Mahatma Lanuru

Seaweed cultures were very prospective for alternative job by community in coastal and small Island. Site selection of culture by inventory and mapping activity of waters resource make up initial stage of important done. This research aimed to determine of waters suitable for development of seaweed culture in Batua Reef, Badi Island, Pangkep Regency, South Sulawesi. Research conduct by survey method to obtain primary data with Geographical Information System (GIS) and secondary data. Data were analysis with PATTERN (Planning Assisstance Through Technical Evaluation of Relevant Numbers) method based on scoring of key variables to determine of suitable level of waters for development of seaweed culture. Result of research showed that Batua Reef waters have area potential for seaweed culture with most suitable were 42,1 ha (4.2\%) as wide, moderately suitable were 660.3 ha (66.6\%) as wide, and low suitable were $156.8 \mathrm{ha}(15,8 \%)$ as wide.

KEYWORDS: culture area, seaweed, reef, Pangkep Regency 


\section{PENDAHULUAN}

Reorientasi kebijakan pemerintah untuk mengoptimalkan pemanfaatan potensi sumberdaya perairan bagi sebesar-besarnya kemakmuran rakyat merupakan keputusan yang sangat tepat. Dari sekian banyak potensi di perairan, sektor perikanan merupakan sektor utama yang dapat dikembangkan sebagai upaya memacu pemulihan perekonomian nasional. Dalam membangun sektor perikanan, Departemen Kelautan dan Perikanan mengeluarkan suatu kebijakan revitalisasi perikanan dengan menetapkan 3 (tiga) komoditas unggulan dalam rangka mewujudkan program tersebut. Ketiga komoditas tersebut adalah udang, tuna, dan rumput laut.

Penetapan komoditas rumput laut sebagai komoditas unggulan didasari atas beberapa pertimbangan, di antaranya: (1) sumberdaya lahan yang dimiliki Indonesia sangat luas yang ditunjang oleh beberapa karakteristik yang sangat prospektif bagi usaha pengembangan budidaya rumput laut, (2) berbagai sumber mineral yang terkandung di dalam produk rumput laut dan pemanfaatan secara luas dalam pangan, farmasi, mikrobiologi, dan medis serta pakan, kosmetika, pupuk, dan industri pengemas (Nurdjana, 2005; Husaini, 2006).

Pengembangan budidaya rumput laut mempunyai prospek yang sangat baik; di samping potensi sumberdaya lahan yang sangat besar, juga ditunjang beberapa karakteristik yang lain (Nurdjana, 2005), yaitu: (1) teknologi budidayanya cukup sederhana, (2) tidak diperlukan modal yang besar, (3) usaha yang sangat menguntungkan, (4) dapat dilakukan secara massal/hamparan, (5) periode pemeliharaan sangat singkat, (6) permintaan sangat besar, (7) menyerap tenaga kerja, dan (8) produk olahan beragam.

Dalam rangka pembangunan kelautan dan perikanan yang berkelanjutan, maka ada 5 tahapan yang harus dilakukan oleh pemerintah sesuai dengan kewenangan pengelolaannya untuk dapat memperoleh hasil yang optimal dan berkelanjutan (Dahuri, 2003). Kelima tahapan tersebut, meliputi: (1) kegiatan inventarisasi dan pemetaan potensi sumberdaya lahan (merupakan tahapan awal yang harus dilakukan), (2) penataan ruang wilayah pesisir, (3) rencana investasi dan pengembangannya sesuai dengan peta tata ruang yang dihasilkan, (4) kebijakan/tahapan-tahapan pengelolaan, (5) menciptakan sistem usaha yang kondusif.

Mengingat banyaknya faktor pembatas yang dapat menentukan cocok tidaknya suatu lokasi untuk pengembangan budidaya rumput laut, maka pemilihan yang tepat serta penentuannya harus didasarkan pada keterpaduan pengaruh dari berbagai faktor tersebut dengan mempertimbangkan secara relatif akan pentingnya pengaruh antara satu faktor dengan faktor yang lainnya.

Salah satu kendala pengembangan budidaya rumput laut pada suatu wilayah perairan adalah belum tersedianya data dan informasi yang akurat tentang luasan lahan dan tingkat kelayakan lokasi untuk pengembangan budidaya rumput laut. Padahal berhasil tidaknya kegiatan budidaya rumput laut sangat erat kaitannya dengan ketepatan dalam pemilihan dan penentuan lokasi yang tepat (Puja et al., 2001). Secara umum pembudidaya masih menentukan lokasi budidaya berdasarkan optimasi yang subjektif, di mana data lokasi dan luasan Iahan hanya sebatas perkiraan-perkiraan yang tidak didukung oleh hasil kajian secara ilmiah dan dilakukan secara profesional. Karena itu, data sering bias dan akan berdampak pada lemahnya perencanaan, kegagalan usaha, serta tumpang tindihnya pemanfaatan ruang baik antar sektor maupun lintas sektor. Sebagai contoh terganggunya kegiatan budidaya rumput laut oleh aktivitas transportasi laut dan semrawutnya budidaya rumput laut yang tersebar di mana-mana (Syaiful et al., 2001). Alternatif lokasi budidaya rumput laut di sekitar pulau-pulau kecil adalah perairan sekitar gusung yang relatif tidak mengganggu aktivitas tranportasi laut serta jauh dari buangan limbah pemukiman.

Pada umumnya masyarakat lokal yang mendiami pulau-pulau kecil di Kabupaten Pangkep memiliki mata pencaharian sebagai nelayan ( $\pm 34 \%)$. Kabupaten Pangkep memiliki luas perairan laut $71.100 \mathrm{~km}^{2}$ dengan garis pantai $250 \mathrm{~km}^{2}$. Sebanyak 117 pulau-pulau kecil dengan luas 35.150 ha di mana 94 pulau berpenghuni dengan jumlah penduduk 51.469 jiwa (Dinas Kelautan dan Perikanan Pangkep, 2007). Oleh sebab itu, perlu dilakukan suatu implementasi kegiatan dalam rangka pengembangan budidaya rumput laut sebagai alternatif pemanfaatan sumberdaya lahan perairan laut, menciptakan lapangan pekerjaan, dan peningkatan kesejahteraan 
masyarakat pulau-pulau kecil di Pangkep. Pengembangan budidaya pada suatu lokasi yang secara visual dapat dimanfaatkan untuk budidaya rumput laut perlu dianalisis lebih lanjut untuk mendapatkan data kelayakan yang akurat.

Penelitian ini bertujuan untuk menentukan kelayakan lahan perairan bagi pengembangan budidaya rumput laut di Gusung Batua, Pulau Badi Kabupaten Pangkep, Sulawesi Selatan. Diharapkan diperoleh data dan informasi tingkat kelayakan lahan sebagai acuan rekomendasi bagi pengguna (pembudidaya rumput laut), sekaligus sebagai masukan bagi pengambil kebijakan untuk pengembangan budidaya rumput laut di Kabupaten Pangkep.

\section{BAHAN DAN METODE}

\section{Lokasi dan Waktu Penelitian}

Survai dilakukan di perairan Gusung Batua, Pulau Badi Kabupaten Pangkep, Sulawesi Selatan (Gambar 1) pada bulan November 2008. Pemilihan lokasi yang didasarkan pada potensi pemanfaatan perairan sekitar Gusung Batua sebagai salah satu wilayah perairan yang potensi dan menjadi lokasi kandidat pilihan oleh masyarakat Pulau Badi untuk pengembangan budidaya rumput laut.

\section{Pengumpulan Data dan Sampel}

Pengumpulan data dilakukan dengan metode survai yang dirancang berdasarkan Sistem Informasi Geografis (SIG). Penentuan titik pengambilan contoh dilakukan secara acak, sesuai dengan kebutuhan dan penyebaran titik sampling yang dianggap mewakili daerah penelitian secara keseluruhan (Morain, 1999). Pengumpulan data primer dengan melakukan pengukuran langsung di lapangan selama survai terhadap peubah kualitas lingkungan perairan yang meliputi: keterlindungan lokasi, luasan, kedalaman perairan dengan menggunakan alat Echosounder-GPS Garmin 178C, suhu, salinitas, $\mathrm{pH}$, dan oksigen terlarut dengan $\mathrm{DO}$ meter merk YSI 650 MDS, kecerahan perairan menggunakan secchi disk, dan kecepatan arus dengan layang-layang arus. Penentuan tingkat pencemaran di lokasi survai dilakukan dengan pendekatan bioindikator diversitas plankton dengan menghitung nilai Resiprok Indeks Diversitas (RID). Pengumpulan contoh plankton dengan menggunakan alat plankton net yang ditarik secara vertikal dari kolom air.

Pengamatan peubah kimia meliputi salinitas dengan menggunakan refraktometer, fosfat $\left(\mathrm{PO}_{4}\right)$ dengan ascorbic acid, nitrat $\left(\mathrm{NO}_{3}-\mathrm{N}\right)$ dengan reduksi cadmium, BOT, dan TSS yang

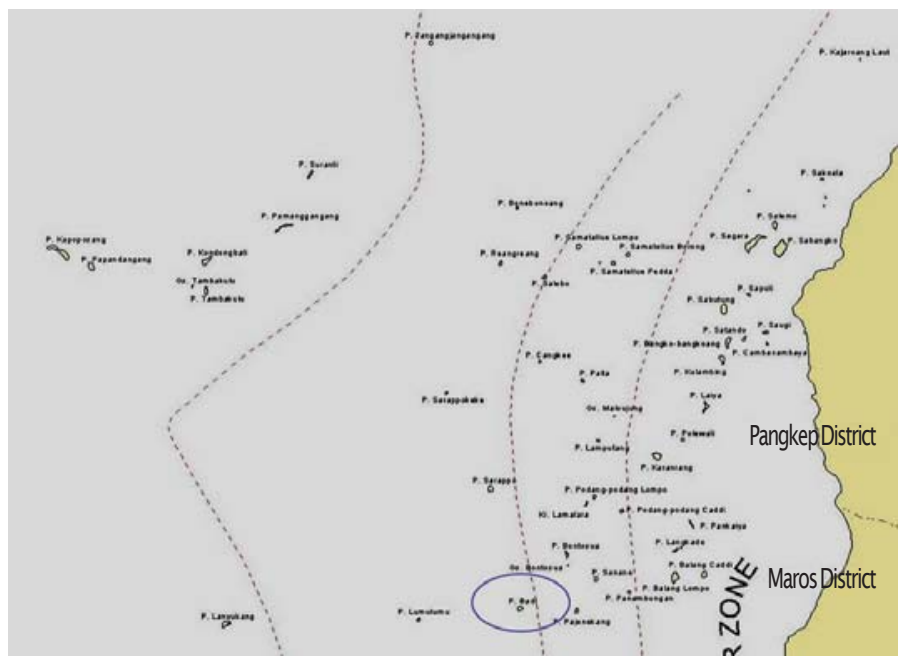

Gambar 1. Lokasi survai (dalam lingkaran) pada wilayah perairan Gusung Batua di sekitar Pulau Badi Kabupaten Pangkep

Figure 1. Survey area (in the circle) in the Batua Reef waters around Badi Island Pangkep District 
dianalisis secara exsitu di laboratorium. Data primer lain yang diambil adalah tekstur sedimen dasar perairan dengan menggunakan grab sampler.

Data sekunder berupa data kondisi umum masyarakat dan sumberdaya kelautan Pulau Badi, geografi Gusung Batua dan Pulau Badi diperoleh melalui wawancara dengan masyarakat lokal, pengumpulan data dari kantor desa, serta lembaga COREMAP II Pulau Badi. Peta rupa bumi dari Bakosurtanal, dan peta dasar serta peta batimetri melalui proses digitasi di laboratorium GIS.

Evaluasi kelayakan dilakukan dengan metode PATTERN (Planning Assisstance Through Technical Evaluation of Relevant Numbers), suatu metode yang diterapkan untuk memecahkan masalah melalui penentuan skor/bobot pada setiap kategori di setiap faktor dari informasi geografis, dilanjutkan dengan menghitung tingkat relatif kontribusi dari setiap faktor lahan secara geografis sampai pada tujuan akhir berupa peta tematik untuk kelayakan pengembangan budidaya rumput laut (Bakosurtanal, 1995 dalam Radiarta et al., 2004). Pada metode ini setiap faktor ditentukan dengan angka skor, dan total skor dihitung dari jumlah pembobotan dari setiap skor kategori. Bobot tersebut ditentukan berdasarkan ketergantungan dari setiap faktor sesuai dengan tujuan pemetaan.

\section{Analisis Data}

Data yang dikumpulkan selanjutnya dianalisis secara spasial, dengan terlebih dahulu melakukan interpolasi untuk mengubah data yang dalam bentuk titik menjadi area (polygon). Cara interpolasi ini menggunakan pendekatan Nearest Neighbour (Burrough \& McDonnell, 1998). Hasil interpolasi dari masing-masing

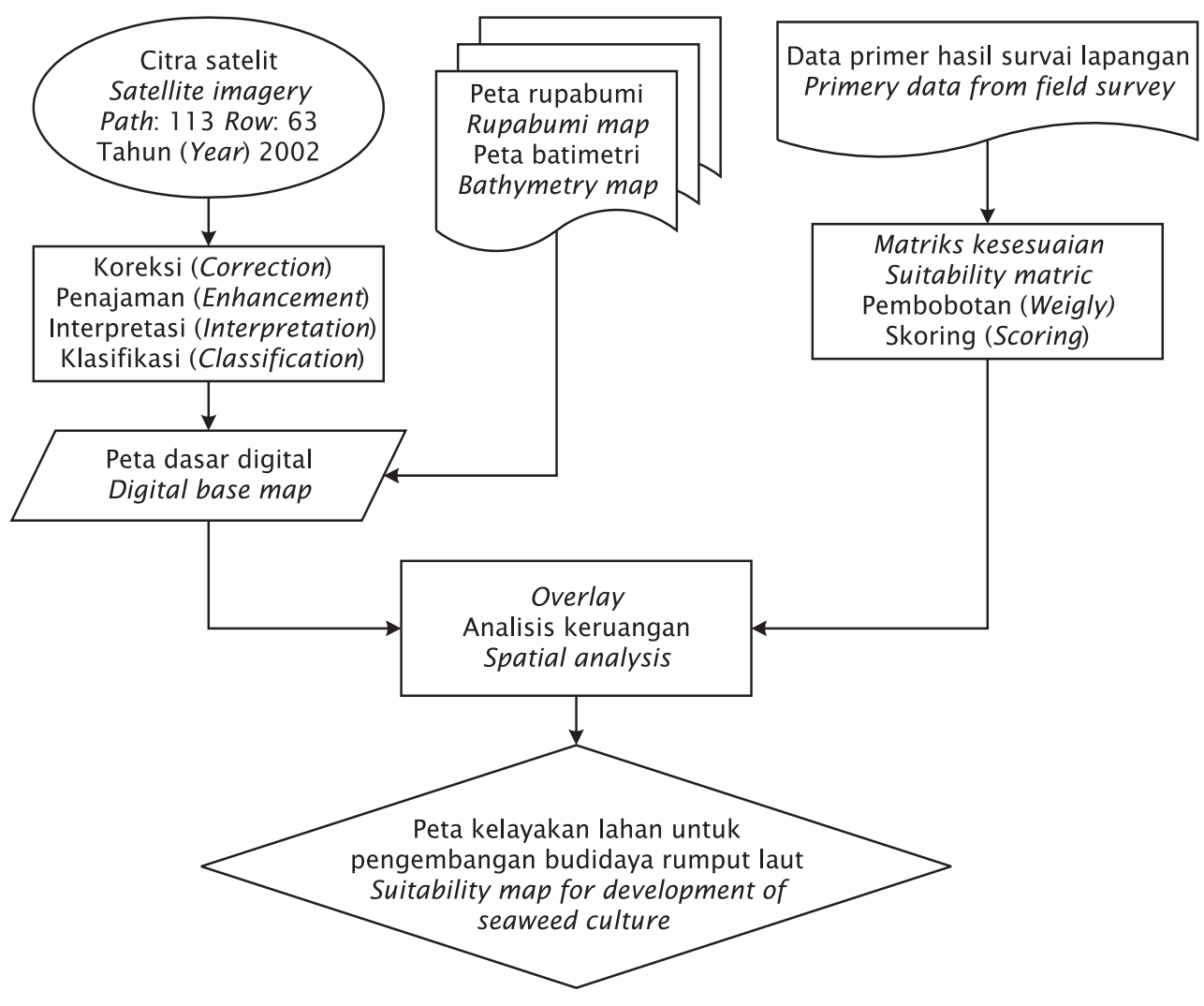

Gambar 2. Diagram alur penentuan kelayakan lahan untuk pengembangan budidaya rumput laut

Figure 2. Flow chart for determining the suitability area for seaweed culture development 
Tabel 1. Matrik kesesuaian lahan berdasarkan parameter kualitas lingkungan perairan untuk pemilihan lokasi budidaya rumput laut

Table 1. Suitability area matrix based on water quality parameters for seaweed culture site selection

\begin{tabular}{|c|c|c|}
\hline $\begin{array}{l}\text { Parameter } \\
\text { Variables }\end{array}$ & $\begin{array}{c}\text { Bobot } \\
\text { Weightly }\end{array}$ & $\begin{array}{l}\text { Skoring } \\
\text { Scoring }\end{array}$ \\
\hline \multicolumn{3}{|l|}{ Ke te rlindungan (Morphology): } \\
\hline - Terlindung (Clouse) & & 3 \\
\hline - Cukup terlindung (Moderately) & & 2 \\
\hline - Terbuka (Open) & 20 & 1 \\
\hline \multicolumn{3}{|l|}{ Kecepatan arus (Current velocity) $(\mathrm{cm} / \mathrm{dt}$ ): } \\
\hline$-20-30$ & & 3 \\
\hline$-31-40$ & & 2 \\
\hline$-<20 \&>40$ & 15 & 1 \\
\hline \multicolumn{3}{|l|}{ Kedalaman air (Water depth) (m): } \\
\hline$-3-10$ & & 3 \\
\hline$-11-15$ & & 2 \\
\hline$-<3 \&>15$ & 15 & 1 \\
\hline \multicolumn{3}{|l|}{ Substrat dasar (Sediment): } \\
\hline - Pasir/pecahan karang (Sand and rubble) & & 3 \\
\hline - Pasir berlumpur (Sandy clay) & & 2 \\
\hline - Lumpur (Clay) & 15 & 1 \\
\hline \multicolumn{3}{|l|}{$\overline{\text { Salinitas (Salinity) (ppt): }}$} \\
\hline$-32-34$ & & 3 \\
\hline$-28-31$ & & 2 \\
\hline$-<28 \&>34$ & 15 & 1 \\
\hline \multicolumn{3}{|l|}{ Kecerahan (Transparancy) (m): } \\
\hline$->3$ & & 3 \\
\hline$-1-3$ & & 2 \\
\hline$-<1 \&>3$ & 10 & 1 \\
\hline \multicolumn{3}{|l|}{ Pencemaran (Pollutant): } \\
\hline - Rendah (Low) & & 3 \\
\hline -Sedang (Moderat) & & 2 \\
\hline - Tinggi $(H i g h)$ & 10 & 1 \\
\hline
\end{tabular}

peubah kualitas lingkungan perairan Gusung Batua yang diperoleh kemudian disusun dalam bentuk layer-layer yang dapat menggambarkan tema-tema tertentu sesuai dengan karakteristik dari lahan tersebut. Setelah seluruh variabel dalam bentuk peta tematik ditumpangtindihkan maka akan diperoleh luasan perairan dengan tingkat kelayakan untuk dijadikan sebagai lokasi pengembangan budidaya rumput laut. Tingkat kelayakan luasan lahan perairan yang ter-cover selama survai dikategorikan, sebagai berikut: kelayakan tinggi, sedang, rendah, dan tidak layak. Bagan alur kerja penentuan kelayakan 
lokasi untuk budidaya rumput laut sesuai dengan tingkatan tersebut diperlihatkan pada Gambar 2.

Kriteria yang digunakan di dalam penyusunan matriks kesesuaian lahan untuk budidaya rumput laut (Tabel 1) mengacu pada Mubarak et al. (1990), Puja et al. (2001); Utojo et al. (2004), dan Radiarta et al. (2004).

Penilaian secara kuantitatif terhadap tingkat kelayakan lahan dilakukan dengan metode skoring dan pembobotan. Bobot yang besar diberikan kepada peubah yang mempunyai pengaruh dominan serta relatif tidak dapat diubah (sifatnya permanen) terhadap peruntukan wilayah tersebut, sebaliknya peubah yang kurang dominan diberi bobot yang lebih kecil. Analisis secara kuantitatif ditentukan dengan menggunakan rumus, sebagai berikut:

$$
Y=\Sigma a_{i} \cdot X_{n}
$$

di mana:

$Y=$ Nilai akhir

$\mathrm{a}_{\mathrm{i}}=$ Faktor pembobot

$\mathrm{X}_{\mathrm{n}}=$ Nilai kesesuaian lahan

Dari hasil perhitungan tersebut akan dapat diperoleh kisaran persentase dari setiap kategori sebagai berikut:

Kelayakan tinggi : $Y=90 \%-100 \%$

Kelayakan sedang : $\mathrm{Y}=70 \%-89 \%$

Kelayakan rendah : $Y=50 \%-69 \%$

Tidak layak $\quad: Y=<50 \%$

Tingkat pencemaran perairan di Gusung Batua ditentukan melalui pendekatan indeks diversitas plankton, yaitu nilai Resiprok Indeks Diversitas (RID) dari Simpson (Odum, 1963) berdasarkan rumus, sebagai berikut:

$$
(1-D)=1-\Sigma \frac{(n i)^{2}}{N^{2}}
$$

di mana:

$(1-D)=$ Resiprok Indeks Diversitas (RID) Simpson

$\mathrm{N} \quad=$ Jumlah total individu

$\mathrm{ni}=$ Jumlah individu masing-masing spesies

Kriteria nilai Resiprok Indeks Diversitas (RID) Simpson:

RID > 0,8: Terjadi pencemaran ringan atau kualitas kehidupan baik

RID 0,6-0,8 : Terjadi pencemaran sedang atau kualitas kehidupan sedang
RID $<0,6$ : Terjadi pencemaran berat atau kualitas kehidupan rusak

\section{HASIL DAN BAHASAN}

\section{Kondisi Umum Lokasi Riset}

Kawasan Gusung Batua merupakan perairan semi terbuka karena terletak di antara beberapa pulau kecil di sekitarnya, yakni dengan: Pulau Badi di sebelah selatan, Pulau Sarappo di sebelah utara, Pulau Lumu-Lumu di sebelah barat, dan Pulau Bonto Sua di sebelah timur. Secara geografis Gusung Batua terletak pada posisi $119^{\circ} 24^{\prime} 23,90^{\prime \prime}$ sampai $119^{\circ} 28^{\prime} 91,20^{\prime \prime}$ BT dan 0425'38,40" sampai 0496'59,10" LS. Gusung Batua mudah terjangkau dari Pulau Badi dengan jarak \pm $4 \mathrm{~km}$ sehingga dapat ditempuh dengan menggunakan perahu mesin selama 10-15 menit. Akses ke Gusung Batua melalui Pulau Badi dengan menggunakan kapal bermesin 12-15 PK dapat ditempuh selama 2-3 jam dari Pelabuhan Paotere, Makassar. Perjalanan laut dari Kota Pangkep dapat ditempuh dalam waktu sekitar 3-4 jam dan dari kota Maros dengan perjalanan laut dan sungai dapat ditempuh dengan waktu 2-2,5 jam.

Berdasarkan informasi dari masyarakat Pulau Badi bahwa Gusung Batua baru muncul 3-4 tahun yang lalu di mana gundukan pasir hanya terlihat pada saat surut terendah di atas taka. Masyarakat lokal mengenal Gusung Batua sebagai gabungan dari beberapa taka, yaitu Batu Lurea, Bone Lantang, Ombonga, dan Batu Bonea. Di sekitar wilayah perairan Gusung Batua terdapat satu palung di tengah gusung yang dikenal dengan nama lembah Katoang. Saat ini di wilayah perairan gusung belum ada kegiatan budidaya rumput laut yang dilakukan masyarakat lokal.

Secara administratif Gusung Batua terletak dalam lingkungan Desa Mattiro Deceng Kecamatan Liukang Tuppabiring Kabupaten Pangkep, Sulawesi Selatan. Luas wilayah daratan Pulau Badi seluas 6,05 ha dengan letak geografi antara $04^{\circ} 56^{\prime} 11.9 "$ sampai

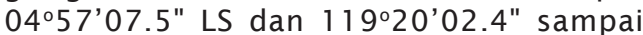
$119^{\circ} 21^{\prime} 06.0^{\prime \prime}$ BT di mana desa ini berbatasan dengan Desa Mattiro Bone di sebelah utara, Desa Mattiro Langi di sebelah barat, Kelurahan Barranglompo di sebelah selatan, dan perairan Makassar di sebelah timur (Mahfud, 2008). Sebagian besar masyarakat Pulau Badi memiliki mata pencaharian sebagai nelayan, kemudian 


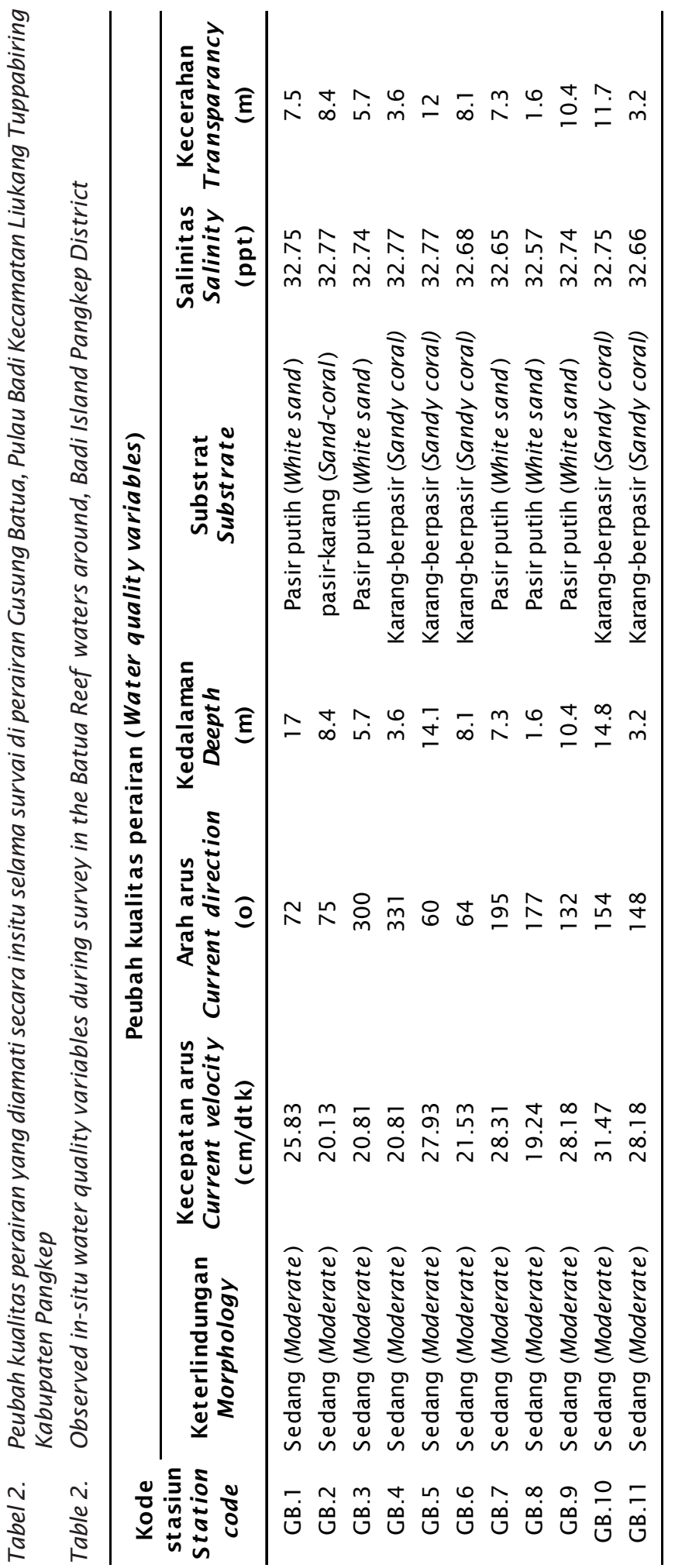


sebagai pedagang, dan beberapa mata pencaharian dengan jumlah yang kecil.

\section{Kondisi Lahan Perairan}

Hasil survai kualitas lingkungan perairan Gusung Batua pada titik-titik pengamatan dan pengambilan contoh air serta sedimen dasar (Tabel 2), secara umum memperlihatkan nilai yang berbeda antar stasiun sehingga tingkat variasinya membutuhkan analisis lanjut untuk kegiatan budidaya rumput laut.

Kondisi kualitas perairan kecepatan arus, substrat, salinitas, dan kecerahan umumnya berada dalam kondisi optimal bagi pertumbuhan rumput laut. Kondisi dimungkinkan karena lokasi yang jauh dari kegiatan pemukiman serta kegiatan lain yang dapat berpengaruh. Kondisi keterlindungan dan tingkat pencemaran perairan Gusung Batua dikategorikan sedang, serta kedalaman yang cukup bervariatif.

\section{Keterlindungan}

Perairan untuk kegiatan budidaya rumput laut harus terlindung dari hempasan langsung ombak yang kuat. Bagian lokasi perairan yang menghadap ke laut lepas sebaiknya terdapat karang penghalang (barrier reef) atau karang tepi (fringing reef) yang berfungsi sebagai pemecah ombak, sehingga dapat melindungi tanaman di lokasi budidaya dari kerusakan karena ombak.

Berdasarkan morfologi perairan Gusung Batua, maka perairan ini merupakan perairan semi terbuka (Gambar 3) karena terletak di antara beberapa pulau kecil di sekitarnya. Walaupun berbatasan dengan beberapa pulau, tetapi keberadaan pulau-pulau kecil tersebut cukup jauh, sehingga sangat kecil dampak keterlindungan gusung dari hempasan ombak yang besar. Dengan berdasarkan pada tingkat keterlindungan, maka perairan dikategorikan dalam tingkat kelayakan sedang. Menurut Ahmad et al. (1996), pengembangan usaha budidaya perikanan pesisir berbasis budidaya laut dapat dilakukan pada kawasan pesisir seperti selat, teluk, laguna, dan gusung yang terlindung dari pengaruh arus kuat, gelombang besar, angin yang kencang serta bebas cemaran.

\section{Kecepatan arus}

Kecepatan arus merupakan faktor ekologi yang primer untuk memungkinkan terjadinya
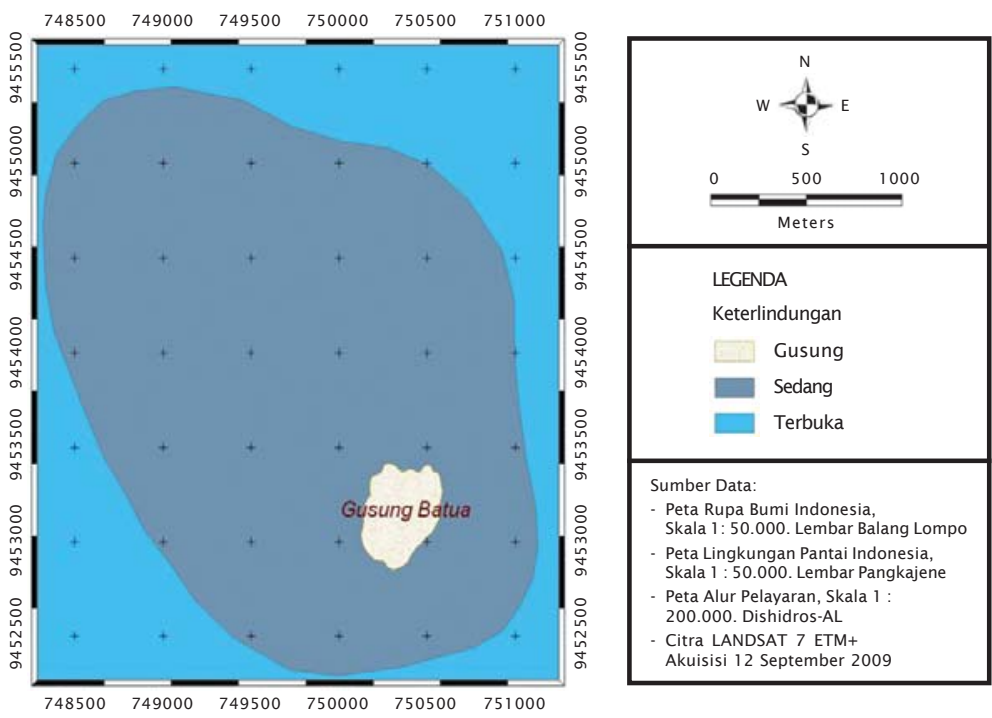

Gambar 3. Peta kondisi keterlindungan lahan di perairan Gusung Batua, Pulau Badi Desa Mattiro Deceng Kecamatan Liukang Tuppabiring Kabupaten Pangkep

Figure 3. Thematic map of protective condition in the Batua Reef waters around Badi Island Pangkep District 

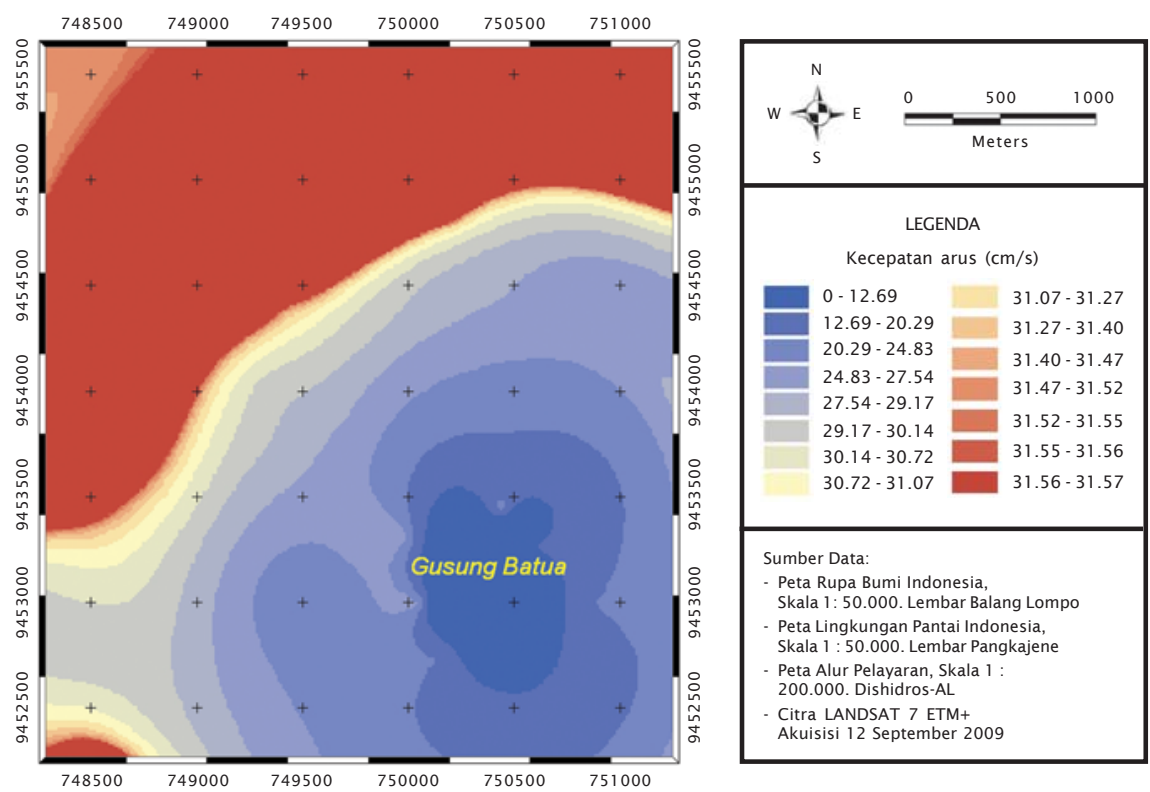

Gambar 4. Peta kondisi kecepatan arus di perairan Gusung Batua, Pulau Badi Desa Mattiro Deceng Kecamatan Liukang Tuppabiring Kabupaten Pangkep

Figure 4. Thematic map of current velocity in the Batua Reef waters around Badi Island Pangkep District

aerasi, tanaman dapat memperoleh unsur hara secara tetap, terhindar dari bahan-bahan tersuspensi dalam air (silt) dan epiphyt. Arus sangat bermanfaat dalam menyuplai dan meningkatkan difusi unsur hara ke dalam jaringan tanaman serta menyebabkan fluktuasi salinitas dan suhu yang kecil. Tanaman yang kotor karena tertutup oleh endapan tidak dapat tumbuh baik karena kesempatan untuk menyerap makanan dari air dan kesempatan berfotosintesis terhalang.

Berdasarkan hasil pengukuran kecepatan arus di perairan Gusung Batua berkisar antara 19,24-31,47 cm/detik dengan peta kondisi pada Gambar 4. Kisaran nilai tersebut relatif masih dalam kategori layak untuk kegiatan budidaya rumput laut. Kecepatan arus 19,24 $\mathrm{cm} /$ detik hanya ditemukan pada satu titik pengamatan (stasiun Gambar 8) karena adanya penghalang gundukan gusung yang mengalangi gerakan arus dari arah barat, namun masih mendekati nilai yang optimal. Perairan yang diinginkan untuk kegiatan budidaya rumput laut memiliki gerakan air yang mampu untuk membawa unsur hara secara merata yaitu dengan kecepatan arus berkisar
20-40 cm/detik (Mubarak et al., 1990). Pergerakan air dianggap sebagai kunci di antara faktor-faktor oseanografi lain karena massa air dapat menjadi homogen dan pengangkutan zat-zat makanan berlangsung lebih baik dan lancar (Aslan, 1998). Di samping itu, arus juga dapat membersihkan tanaman rumput laut dari kotoran yang menempel (Anonim, 1991). Tanaman yang kotor karena tertutup oleh endapan tidak dapat tumbuh baik karena kesempatan untuk menyerap makanan dari air dan kesempatan berfotosintesis terhalang (Anonim, 1990). Homogenitas kesuburan lokasi tanaman rumput laut sangat ditentukan oleh adanya gerakan air yang berombak maupun arus. Ombak dan arus merupakan alat pengaduk yang baik sehingga air menjadi homogen.

Pola pergerakan arus permukaan di perairan Gusung Batua dipengaruhi oleh pola arus yang terjadi dari pecahan ombak di perairan pulaupulau kecil di sekitar gusung dan kondisi pasang surut di perairan sekitarnya. Berdasarkan pola pergerakan arus dan ombak, lokasi perairan Gusung Batua tergolong ke dalam tingkat kelayakan tinggi. 


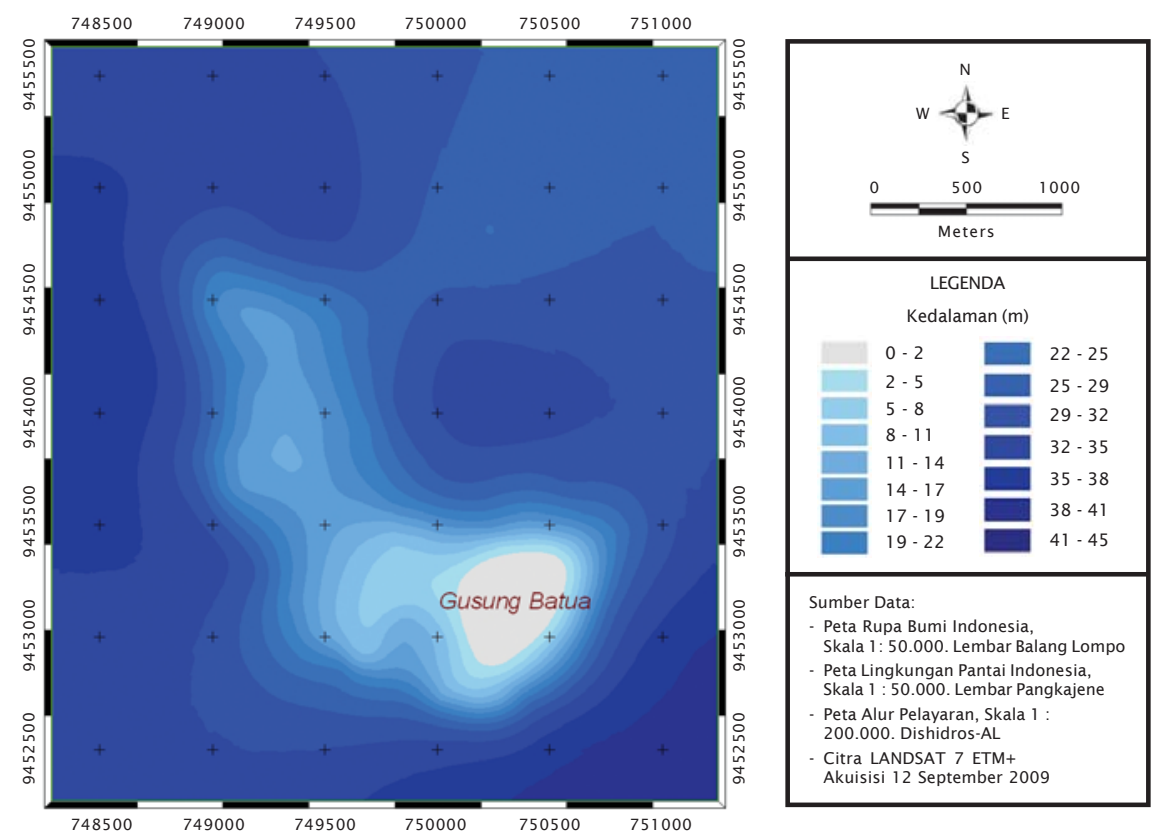

Gambar 5. Peta kondisi kedalaman di perairan Gusung Batua, Pulau Badi Desa Mattiro Deceng Kecamatan Liukang Tuppabiring Kabupaten Pangkep

Figure 5. Thematic map of bathymetry in the Batua Reef waters around Badi Island Pangkep District

\section{Kedalaman perairan}

Perairan yang selalu terendam (Sub-tidal) merupakan lahan yang cocok untuk budidaya rumput laut sehingga tanaman akan selalu terendam dalam air dan mendapat peluang penyerapan makanan secara terus-menerus serta menghindari kerusakan tallus dari sengatan matahari. Walaupun demikian, perairan dengan kedalaman yang tinggi (> 10 m) akan membutuhkan input biaya yang tinggi untuk konstruksi lokasi budidaya rumput laut.

Perairan Gusung Batua memiliki topografi dasar perairan dan kedalaman yang sangat bervariasi (Gambar 5) antara 1,60 sampai 36,80 $( \pm 10,95) \mathrm{m}$ mulai di sekitar gundukan pasir gusung sampai ke arah laut lepas.

Kedalaman perairan selama survai dipengaruhi oleh perubahan pasang dan kontur dasar gusung. Terlihat selama survai pada saat pasang tinggi maka dasar gusung yang tertinggi tertutup air laut, dan sebaliknya pada saat surut rendah maka terdapat daratan gusung yang cukup luas sebagai tempat persinggahan burung-burung laut.

\section{Substrat dasar}

Dasar perairan agak keras yang dibentuk oleh pasir dan pecahan karang berwarna putih serta bebas dari sedimen dan lumpur sangat layak untuk budidaya rumput laut. Sebaliknya, substrat yang secara keseluruhan karang hidup menandakan bahwa perairan tersebut selalu mendapat pukulan ombak, sehingga kurang bagus untuk budidaya rumput laut.

Hasil pengamatan sedimen dan substrat dasar perairan Gusung Batua terdiri atas pasirpecahan karang-karang (Gambar 6). Hal ini menunjukkan bahwa jenis substrat dasar perairan yang merupakan indikator habitat yang cocok untuk pertumbuhan rumput laut. Selain berpengaruh terhadap kemudahan pemasangan fasilitas budidaya, substrat juga dapat berpengaruh terhadap produktivitas perairan, kekeruhan, dan sedimentasi. Menurut Mayunar et al. (1995), perairan tempat kegiatan budidaya rumput laut sebaiknya memiliki dasar berpasir atau karang, airnya jernih dan terhindar dari pelumpuran (siltasi) karena dapat mempengaruhi perkembangan tallus dan mutu air. Pertumbuhan tanaman rumput laut 


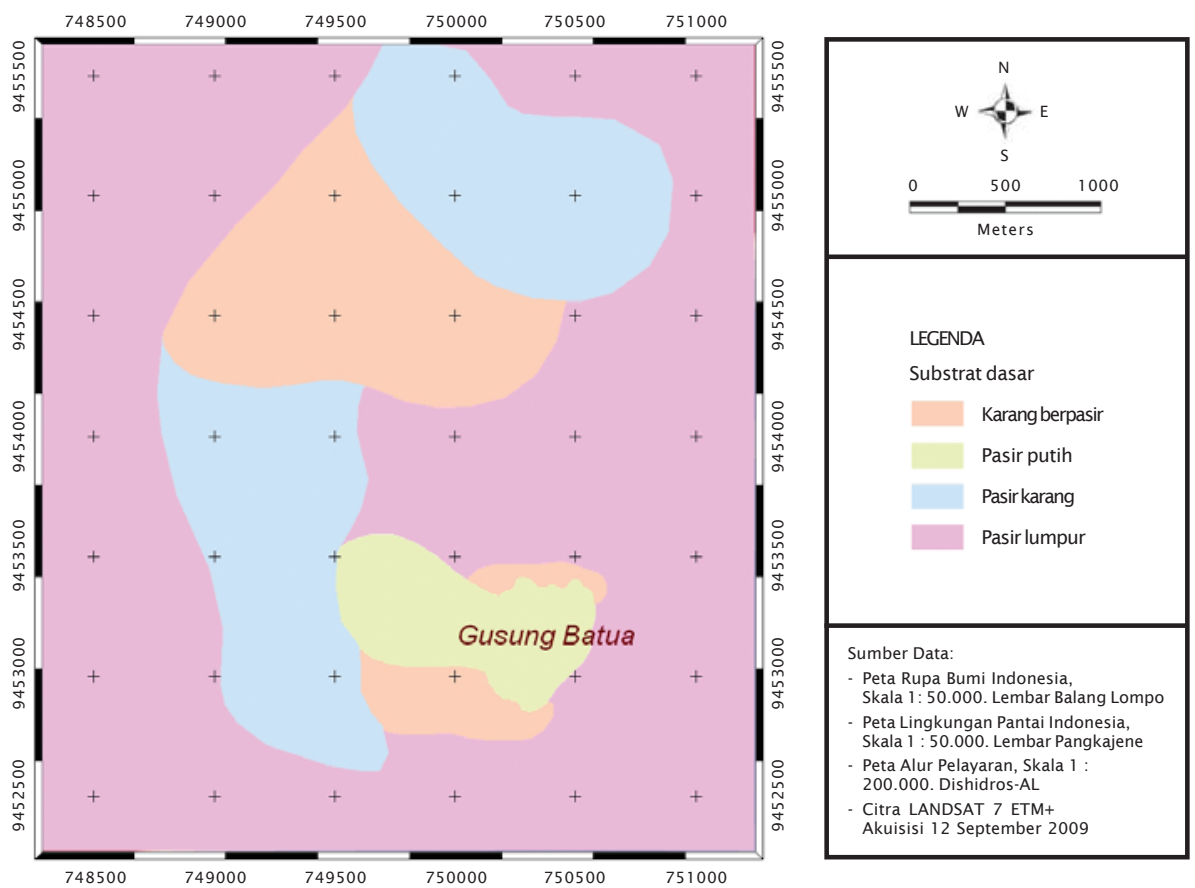

Gambar6. Peta kondisi substrat dasar di perairan Gusung Batua, Pulau Badi Desa Mattiro Deceng Kecamatan Liukang Tuppabiring Kabupaten Pangkep

Figure 6. Thematic map of seabed (substrate) in the Batua Reef waters around Badi Island Pangkep District

memerlukan substrat dasar berpasir dan karang dengan pergerakan air lancar (Mubarak et al., 1990).

\section{Salinitas}

Fluktuasi salinitas di luar kisaran yang ideal akan menyebabkan rendahnya pertumbuhan dan cepatnya proses penuaan (aging process) tallus rumput laut (Anonim, 1991). Oleh karena itu, lahan perairan untuk budidaya rumput laut sebaiknya tidak pada lokasi yang mengalami fluktuasi salinitas tinggi.

Salinitas perairan Gusung Batua berkisar 32,57-32,77 ppt dengan kondisi yang cukup stabil (Gambar 7). Salinitas perairan tersebut berada dalam kategori layak untuk kegiatan budidaya rumput laut. Secara keseluruhan salinitas untuk pertumbuhan optimal sekitar 28\%-34\% dengan nilai optimum salinitas 33\%。 (Anonim, 1991; 1992), sedangkan jenis Kappaphycus dan Euchema tumbuh optimal pada salinitas yang tinggi dengan kisaran 3234 ppt (Mubarak et al., 1990).

\section{Kecerahan perairan}

Kecerahan perairan berhubungan dengan proses fotosintesis tallus rumput laut. Air yang keruh mengandung bahan tersuspensi yang melimpah dan akan menutupi tallus rumput laut sehingga menghambat penyerapan unsur hara.

Kecerahan di perairan Gusung Batua terlihat relatif homogen dari tingkat kecerahan 100\% sampai 11,7 m (Gambar 8) di mana tidak terdapat faktor yang dapat memberikan pengaruh variasi untuk setiap titik sampling. Lokasi yang jauh dari daratan dan pemukiman penduduk sehingga tidak ditemukan kemungkinan terjadinya proses sedimentasi dan pencemaran langsung dari limbah organik. Kecerahan tertinggi $(11,7 \mathrm{~m})$ ditemukan pada bagian perairan yang dalam di mana tingkat kecerahan tersebut sangat baik untuk budidaya rumput laut. Untuk kegiatan budidaya rumput laut yang ideal, tingkat kecerahan perairan adalah $>5 \mathrm{~m}$ (Mubarak et al., 1990). Menurut Effendi (2000), nilai 

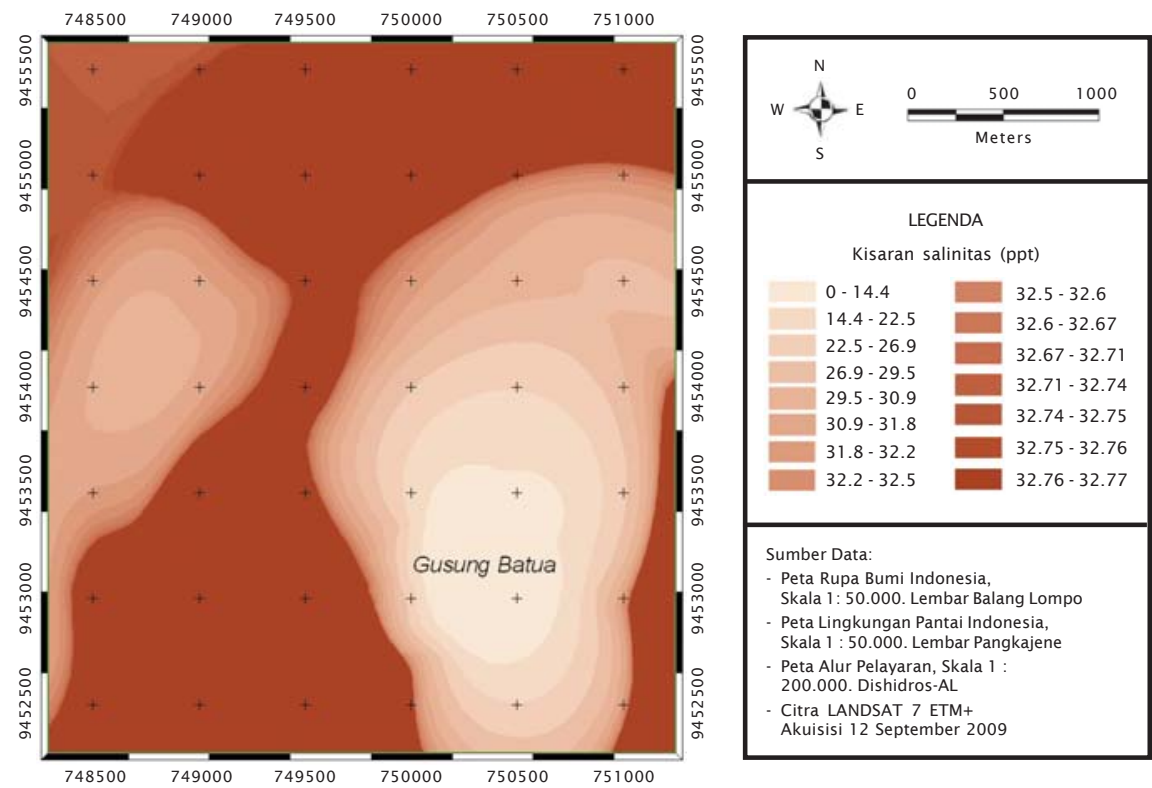

Gambar 7. Peta kondisi salinitas di perairan Gusung Batua, Pulau Badi Desa Mattiro Deceng Kecamatan Liukang Tuppabiring Kabupaten Pangkep

Figure 7. Thematic map of salinity in the Batua Reef waters around Badi Island Pangkep District
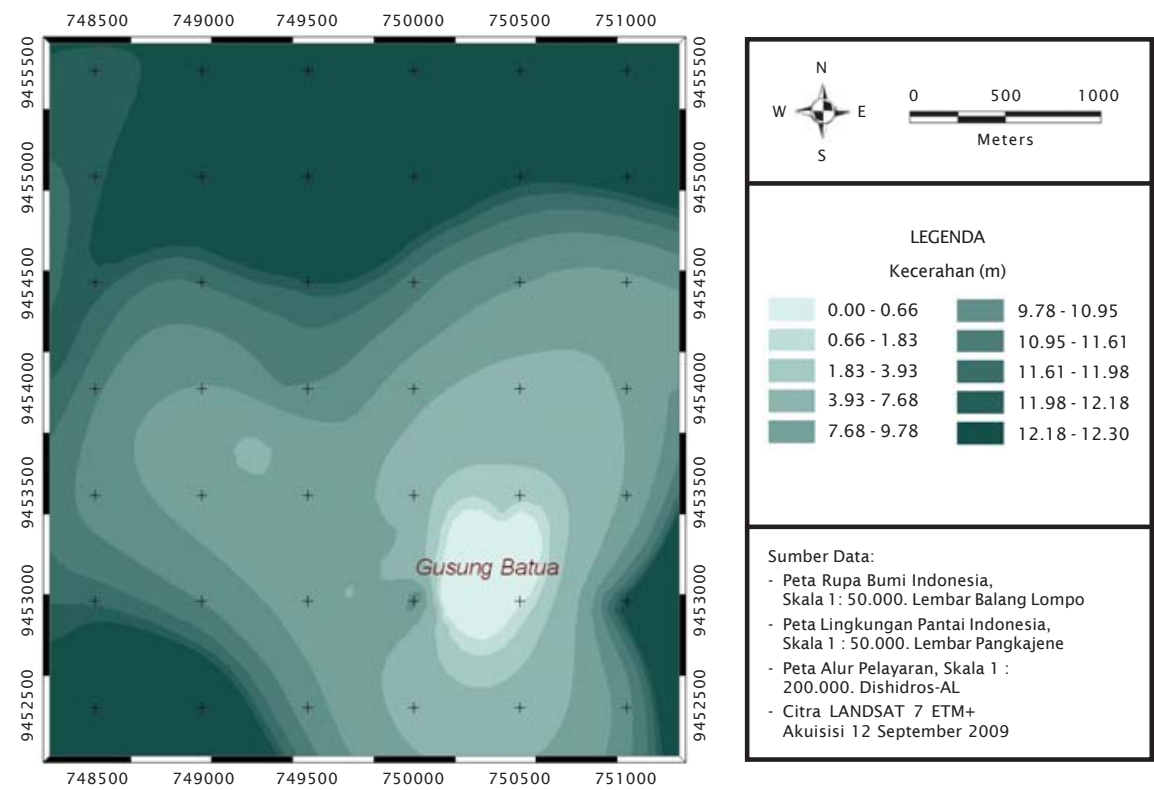

Gambar 8. Peta kondisi kecerahan di perairan Gusung Batua, Pulau Badi Desa Mattiro Deceng Kecamatan Liukang Tuppabiring Kabupaten Pangkep

Figure 8. Thematic map of water clearity in the Batua Reef waters around Badi Island Pangkep District 
kecerahan sangat dipengaruhi oleh keadaan cuaca, waktu pengukuran, kekeruhan, padatan tersuspensi, dan tingkat penglihatan peneliti. Kecerahan perairan menunjukkan kemampuan cahaya untuk menembus lapisan air pada kedalaman tertentu. Faktor-faktor yang dapat mempengaruhi kecerahan adalah kandungan lumpur, kepadatan plankton, dan bahan-bahan terlarut lainnya. Budidaya rumput laut dengan tingkat kecerahan yang tinggi sangat dibutuhkan, sehingga cahaya dapat masuk ke dalam air. Intensitas sinar yang diterima secara sempurna oleh tallus merupakan faktor lingkungan eksternal dalam proses fotosintesis.

\section{Tingkat pencemaran perairan}

Lahan perairan untuk budidaya rumput laut harus bebas dari bahan pencemar, baik dari kegiatan pertanian, pemukiman, maupun industri. Limbah pestisida dan logam berat akan sangat menurunkan mutu dan berbahaya bagi konsumen apabila terakumulasi dalam jaringan rumput laut.

Berdasarkan analisis bioindikator plankton, maka perairan Gusung Batua layak untuk pengembangan budidaya rumput laut karena umumnya masih dalam kategori tercemar ringan sampai sedang (Tabel 3) sebagai indikator bahwa kualitas kehidupan masih baik. Selanjutnya diperlihatkan peta kondisi pencemaran perairan di Gusung Batua (Gambar 9).

Analisis tingkat pencemaran suatu lokasi perairan dapat dilakukan melalui pengukuran kuantitatif dengan cara kimiawi, tetapi membutuhkan biaya, waktu, dan tenaga yang banyak. Kelayakan lingkungan untuk usaha budidaya dapat diestimasi melalui bioindikator jenis-jenis biota yang menghuni perairan tersebut. Plankton merupakan organisme yang sering digunakan dalam keperluan tersebut karena studi ekologinya murah dalam biaya, mudah dalam pelaksanaan dan efektif dalam hasil yang diperoleh. Peran organisme tersebut di dalam ekosistem akuatik, antara lain: sebagai bagian dari rantai makanan dalam sumberdaya perikanan (Odum, 1971) dan sebagai bioindikator perubahan lingkungan (Hawkes, 1976). Plankton memiliki sifat kepekaan terhadap beberapa bahan pencemar, mobilitas yang rendah karena terpengaruh arus, mudah ditangkap serta memiliki sintasan yang panjang. Oleh karena itu, peran plankton dalam
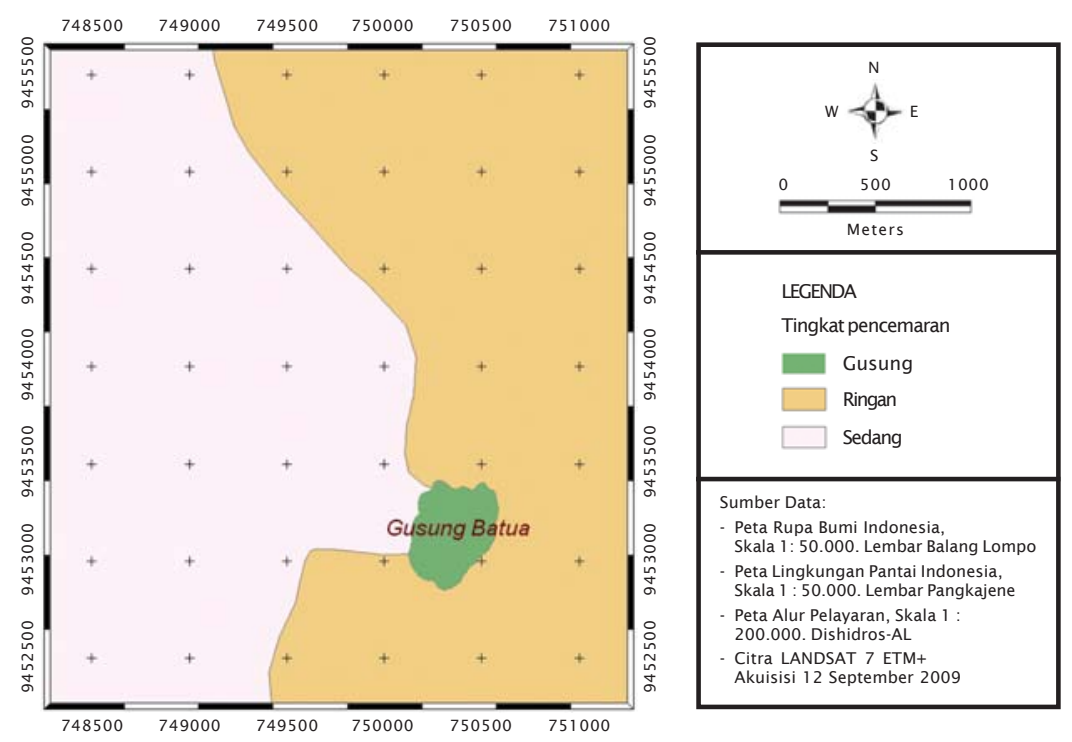

Gambar 9. Peta kondisi pencemaran di perairan Gusung Batua, Pulau Badi Desa Mattiro Deceng Kecamatan Liukang Tuppabiring Kabupaten Pangkep

Figure 9. Thematic map of water pollution in the Batua Reef waters around Badi Island Pangkep District 
Tabel 3. Tingkat kecemaran perairan berdasarkan nilai RID dari indeks biologi plankton di perairan Gusung Batua, Pulau Badi Kabupaten Pangkep

Table 3. Level of water pollution based on RID value extracted from biology of plankton index in the Batua Reef waters around Badi Island Pangkep District

\begin{tabular}{ccccc}
\hline $\begin{array}{c}\text { Stasiun pengamatan } \\
\text { Observed site }\end{array}$ & (ni)2 & N2 & $\begin{array}{c}\text { Nilai (value) } \\
\text { RID }\end{array}$ & $\begin{array}{c}\text { Tingkat kecemaran perairan } \\
\text { Level of wat er pollution }\end{array}$ \\
\hline GB.1 & 4,714 & 21,316 & 0.78 & Sedang (Moderate) \\
GB.2 & 8,886 & 44,944 & 0.80 & Sedang (Moderate) \\
GB.3 & 26,652 & 150,544 & 0.82 & Ringan (Low) \\
GB. 4 & 1,770 & 13,924 & 0.87 & Ringan (Low) \\
GB.5 & 750 & 4,096 & 0.82 & Ringan (Low) \\
GB.6 & 4,123 & 32,041 & 0.87 & Ringan (Low) \\
GB.7 & 5,651 & 20,449 & 0.72 & Sedang (Moderate) \\
GB.8 & 46,643 & 294,849 & 0.84 & Ringan (Low) \\
GB.9 & 6,951 & 28,561 & 0.76 & Sedang (Moderate) \\
GB.10 & 2,700 & 11,236 & 0.76 & Sedang (Moderate) \\
GB.11 & 10,221 & 61,009 & 0.83 & Ringan (Low) \\
\hline
\end{tabular}

keseimbangan suatu ekosistem perairan termasuk lahan budidaya dapat menjadi indikator kondisi ekologi terkini pada suatu kawasan tertentu.

\section{Kualitas perairan pendukung lainnya}

Peubah kualitas perairan yang bersifat fluktuatif (tidak permanen) juga merupakan faktor-faktor pendukung bagi pertumbuhan budidaya rumput laut. Peubah kualitas air ini dipengaruhi oleh musim/cuaca sehingga perlu dipantau secara periodik dalam perairan laut. Hasil analisis kualitas perairan, yang meliputi kandungan: $\mathrm{BOT}, \mathrm{NO}_{3}-\mathrm{N}, \mathrm{PO}_{4}-\mathrm{P}$, dan TSS Gusung Batua (Tabel 4) menunjukkan kisaran nilai yang layak bagi budidaya rumput laut.

Suhu perairan Gusung Batua selama survai berkisar antara $30,12^{\circ} \mathrm{C}-30,71^{\circ} \mathrm{C}$ merupakan kisaran yang cukup ideal dan layak bagi kegiatan budidaya rumput laut. Menurut Nontji (1986), suhu air pada bagian permukaan dipengaruhi oleh kondisi meteorologi seperti curah hujan, penguapan, kelembaban udara, suhu udara, kecepatan angin, dan intensitas radiasi matahari. Oleh sebab itu, suhu di permukaan biasanya mengikuti pola musiman. Suhu air untuk budidaya rumput laut berkisar antara $27^{\circ} \mathrm{C}-30^{\circ} \mathrm{C}$ dan perubahan suhu tidak lebih dari $4^{\circ} \mathrm{C}$ setiap hari (Anonim, 1991; Aslan, 1998). Kenaikan suhu yang tinggi akan mengakibatkan tallus rumput laut menjadi pucat kekuning-kuningan dan tidak sehat, layu, dan mudah terserang penyakit. Suhu berpengaruh langsung terhadap kehidupan rumput laut terutama dalam proses fotosintesis, proses metabolisme, dan siklus reproduksi (Sverderup et al., 1961 dalam Mayunar et al., 1995). Selain itu, fluktuasi suhu yang sangat tinggi akan membuat tanaman menjadi stres dan mempengaruhi laju pertumbuhan.

Nilai $\mathrm{pH}$ perairan menjadi faktor pembatas terhadap kehidupan dan keberadaan suatu tumbuhan. Walaupun air laut memiliki nilai $\mathrm{pH}$ yang relatif stabil tetapi dapat dipengaruhi oleh aktivitas fotosintesis, suhu, serta buangan industri dan rumah tangga. Air laut memiliki nilai $\mathrm{pH}$ yang relatif stabil dan biasanya berkisar antara 7,5-8,4. Nilai pH suatu perairan biasanya tinggi pada sore hari dan rendah pada pagi hari (Mayunar et al., 1995). Rumput laut tumbuh pada $\mathrm{pH}$ 6-9 dan cenderung basa, sedangkan nilai pH perairan yang optimal bagi pertumbuhan Euchema spp. antara 7,5-8,0 (Anonim, 1992; Aslan, 1998).

Kandungan bahan organik total dan padatan tersuspensi total di perairan Gusung Batua yang berkisar 2,35-5,28 mg/L dan 48,74-85,47 mg/L. Kandungan TSS yang cukup rendah dimungkinkan kurangnya pengaruh siltasi dasar laut atau sumber 
Tabel 4. Peubah kualitas perairan Gusung Batua, Pulau Badi Kabupaten Pangkep yang diamati secara exsitu di laboratorium

Table 4. Observed ex-situ water quality variables at laboratory in the Batua Reef waters around Badi Island Pangkep District

\begin{tabular}{cccccccc}
\hline $\begin{array}{c}\text { Lokasi } \\
\text { sampling } \\
\text { Observed } \\
\text { site }\end{array}$ & \multicolumn{6}{c}{ Peubah kualitas air (Parameters of water quality) } \\
\cline { 2 - 8 } & $\begin{array}{c}\text { Suhu } \\
\text { Temperature }\end{array}$ & $\begin{array}{c}\left.{ }^{\circ} \mathrm{C}\right) \\
(\mathbf{m g} / \mathrm{L})\end{array}$ & $\mathbf{p H}$ & $\begin{array}{c}\text { BOT (TOM) } \\
(\mathbf{m g} / \mathrm{L})\end{array}$ & $\begin{array}{c}\mathbf{N O}_{3}-\mathrm{N} \\
(\mathbf{m g} / \mathrm{L})\end{array}$ & $\begin{array}{c}\text { PO }_{4}-\mathrm{P} \\
(\mathbf{m g} / \mathrm{L})\end{array}$ & $\begin{array}{c}\text { TSS } \\
(\mathbf{m g} / \mathrm{L})\end{array}$ \\
\hline B.1 & 30.70 & 8.26 & 7.64 & 3.5265 & 0.0365 & 0.0821 & 61.42 \\
GB.2 & 30.71 & 8.89 & 7.71 & 5.2898 & 0.0413 & 0.0533 & 52.41 \\
GB.3 & 30.28 & 8.86 & 7.68 & 2.3510 & 0.0211 & 0.0912 & 48.74 \\
GB.4 & 30.26 & 4.08 & 7.52 & 4.1143 & 0.0289 & 0.0740 & 51.33 \\
GB.5 & 30.22 & 4.89 & 7.53 & 3.5256 & 0.0350 & 0.0655 & 63.83 \\
GB.6 & 30.12 & 4.94 & 7.60 & 3.5241 & 0.0344 & 0.0384 & 71.44 \\
GB.7 & 30.2 & 4.88 & 7.56 & 3.5265 & 0.0503 & 0.0621 & 65.21 \\
GB.8 & 30.22 & 4.89 & 7.56 & 3.5401 & 0.0424 & 0.0947 & 55.37 \\
GB.9 & 30.37 & 5.98 & 7.58 & 4.0210 & 0.0312 & 0.0645 & 58.24 \\
GB.10 & 30.35 & 5.97 & 7.56 & 3.5540 & 0.0231 & 0.0721 & 68.77 \\
GB.11 & 30.37 & 5.41 & 7.57 & 4.0312 & 0.0281 & 0.0684 & 85.47 \\
\hline
\end{tabular}

sedimentasi pantai, sehingga dinilai masih dalam kisaran kategori baik untuk kegiatan budidaya rumput laut.

\section{Peta Kelayakan Lahan untuk Budidaya Rumput Laut}

Dari hasil analisis dan penentuan tingkat kelayakan lokasi perairan Gusung Batua Pulau Badi di Kepulauan Spermonde Kabupaten Pangkep, maka luasan lahan yang ter-cover seluas 991,3 ha (Gambar 10) dengan tingkat kelayakan tinggi seluas 42,1 ha $(4,2 \%)$, tingkat kelayakan sedang seluas 660,3 ha $(66,6 \%)$, tingkat kelayakan rendah seluas 156,8 ha $(15,8 \%)$. Selebihnya merupakan lahan yang tidak layak seluas 132,1 ha $(13,3 \%)$ terdapat di lapisan sebelah luar dengan kedalaman perairan yang lebih tinggi dari $20 \mathrm{~m}$. Lahan dengan tingkat kelayakan tinggi untuk budidaya rumput laut terdapat di sebelah barat gusung dengan kedalaman 3-10 m.

Dengan pertimbangan luas lahan perairan Gusung Batua yang dapat ditempati oleh rumput laut seluas 702,4 ha (tingkat kelayakan tinggi dan sedang), maka pada kawasan perairan ini dapat ditempati sebanyak 2.810 unit konstruksi tempat budidaya. Apabila setiap tali bentangan yang digunakan panjangnya $25 \mathrm{~m}$ dan jarak pasang $1 \mathrm{~m}$ antar bentangan, maka jumlah tali bentangan per unit usaha adalah sebanyak 100 tali ris atau 4 unit per ha, sehingga kawasan Gusung Batua dapat memuat 2.809.600 tali bentangan.

Untuk pengembangan usaha budidaya rumput laut yang produktif dan berkelanjutan, maka potensi yang ada dapat dimanfaatkan semaksimal mungkin mengingat kawasan lahan penyangga cukup luas tersedia di sekitarnya. Dengan tingkat kelayakan lahan yang sedang, maka pemanfaatan lahan perairan Gusung Batua untuk budidaya rumput laut membutuhkan input teknologi yang lebih tinggi dibandingkan dengan perairan dengan kelayakan tinggi. Akuainput tersebut terutama adalah kontruksi tali induk yang lebih kuat dengan menggunakan jangkar beton untuk menahan kemungkinan arus dan gelombang yang kuat.

Penerapan metode long line dapat diaplikasikan untuk budidaya spesies Kappaphycus alvarezii, Eucheuma denticulatum, dan E. edule. Pada beberapa hasil riset sebelumnya jenis rumput laut dengan beberapa varietas memiliki toleransi yang berbeda terhadap perubahan musim dan kualitas lingkungan perairan (Pong-Masak et al., 2006; 2007; 2008), sehingga jenis-jenis rumput tersebut dapat saling mensubtitusi sesuai dengan musim dan 

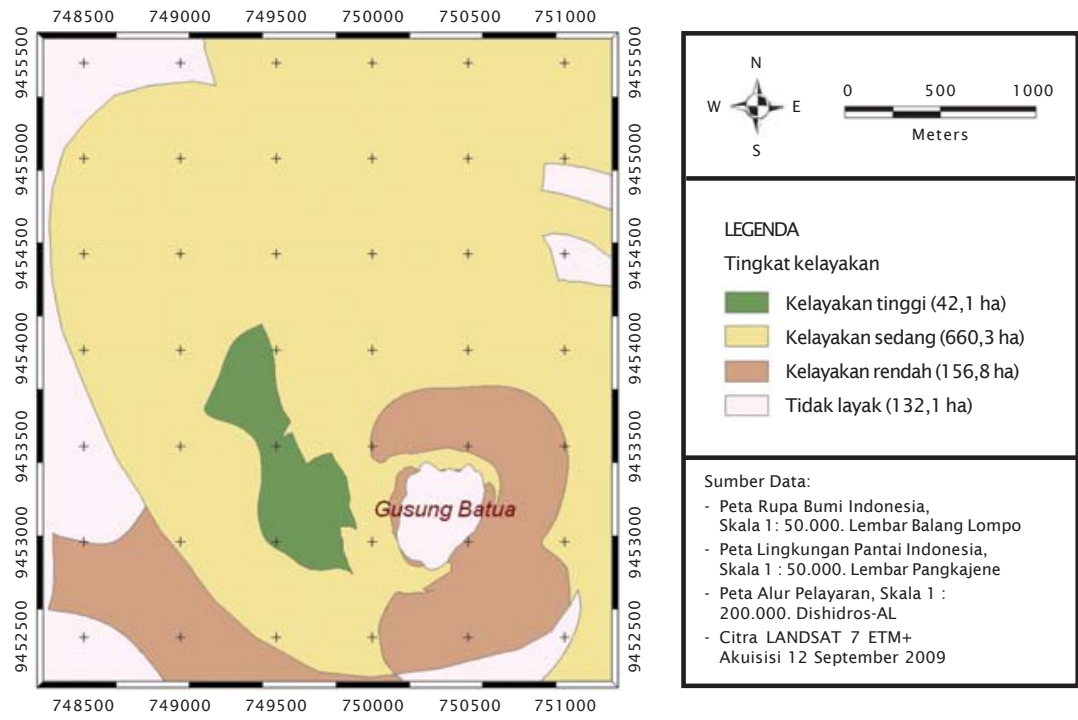

Gambar 10. Peta kelayakan lahan budidaya rumput laut di perairan Gusung Batua, Pulau Badi Kabupaten Pangkep, Sulawesi Selatan

Figure 10. Map of seaweed culture suitability area observed in-situ water quality variables during survey in the Batua Reef waters around Badi Island Pangkep District, South Sulawesi

respons pertumbuhan yang optimal. Metode budidaya long-line lebih disarankan diaplikasikan oleh masyarakat Pulau Badi di Gusung Batua karena relatif mudah memperoleh bahan seperti tali nilon dan bahan pembuatan jangkar beton dari kota Makassar, Maros, dan Pangkep.

Aspek penunjang lain yaitu wilayah perairan yang cukup terjangkau dengan Kota Makassar dan Kota Maros dengan jalur transportasi laut yang cukup lancar menghubungkan Pulau Badi sehingga dapat memudahkan di dalam transportasi pengangkutan benih dan sarana produksi rumput laut saat operasional budidaya. Sebaliknya juga akan memudahkan pengangkutan produksi rumput laut kering hasil budidaya untuk dipasarkan.

\section{KESIMPULAN DAN SARAN}

Beberapa kesimpulan dari hasil penelitian ini, sebagai berikut:

1. Berdasarkan analisis kelayakan lahan, maka Perairan Gusung Batua, Pulau Badi dengan luas 991,3 ha, dapat digunakan sebagai lahan budidaya rumput laut dengan tingkat kelayakan tinggi seluas 42,1 ha $(4,2 \%)$, tingkat kelayakan sedang 660,3 ha $(66,6 \%)$, tingkat kelayakan rendah 156,8 ha $(15,8 \%)$ dan tidak layak seluas 132,1 ha $(13,3 \%)$.

2. Kondisi kualitas perairan Gusung Batua umumnya dalam kriteria yang baik untuk kegiatan budidaya rumput laut, kecuali tingkat keterlindungan dan kedalaman perairan yang memberikan variasi sedang sampai tinggi.

3. Secara geografi, perairan Gusung Batua sangat strategis dan potensi dijadikan lokasi pengembangan budidaya rumput laut oleh masyarakat lokal pulau-pulau di sekitarnya.

\section{Saran dan tindak lanjut, sebagai berikut:}

Sebaiknya pengembangan budidaya rumput laut di Gusung Batua dilakukan secara terpadu, yakni seluruh proses produksi rumput laut kering (pengikatan bibit, pemeliharaan, dan penjemuran) dilakukan di lokasi gusung.

- Rumput laut umumnya tidak tumbuh sepanjang tahun dan berbeda-beda antar suatu kawasan pengembangan. Oleh karena itu, perlu dilakukan kajian lebih lanjut untuk mengetahui musim tanam rumput laut 
yang produktif di Gusung Batua untuk meminimasi kegagalan panen oleh pembudidaya karena kesalahan waktu tanam.

\section{UCAPAN TERIMA KASIH}

Ucapan terima kasih disampaikan kepada Dirjen Kelautan, Pesisir dan Pulau-pulau Kecil, COREMAP II-Sulsel, Konsorsium Program Mitra Bahari Sulawesi Selatan yang telah memfasilitasi kegiatan ini. Ucapan terima kasih yang sama kepada Teknisi Litkayasa di Laboratorium Kualitas Air BRPBAP, Dinas Kelautan dan Perikanan Tk. II Pangkep, CV Abnur Sobur Mandiri, Bapak Ikhsan Mahfud, Bapak Sofyan, dan Dg. Abba yang telah membantu dalam bentuk koordinasi, kerja sama, informasi, dan tenaga selama kegiatan ini berlangsung.

\section{DAFTAR ACUAN}

Ahmad, T., Mustafa, A., \& Hanafi, A. 1996. Konsep Pengembangan Desa Pantai Mendukung Keberlanjutan Produksi Perikanan Pesisir. Dalam Poernomo, A., H.E. Irianto, S. Nurhakim, Murniyati, dan E. Pratiwi (Eds.). Prosiding Rapat Kerja Teknis Peningkatan Visi Sumberdaya Manusia Peneliti Perikanan Menyongsong Globalisasi IPTEK, Serpong, 19-20 November 1996. Badan Litbang Pertanian, Pulsitbang Perikanan, Jakarta, hlm. 91-106.

Anonim. 1990. Budidaya Rumput Laut. Departemen Pertanian. Balai Informasi Pertanian, Riau, $26 \mathrm{hlm}$.

Anonim. 1991. Budidaya Rumput Laut. Departemen Pertanian. Kantor Wilayah DKI Jakarta, $31 \mathrm{hlm}$.

Anonim. 1992. Budidaya Beberapa Hasil Laut. Departemen Pertanian. Badan Pendidikan dan Latihan Pertanian Proyek Pengembangan Penyuluhan Pertanian Pusat (NAEP III), $27 \mathrm{hlm}$.

Aslan, L.M. 1998. Budidaya Rumput Laut. Kanisius, Yogyakarta, $96 \mathrm{hlm}$.

Burrough, P.A. \& R.A. Mc Donnel. 1998. Principle of geografical information systems. Oxford University Press, Oxford, 352 pp.

Dahuri, R. 2003. Paradigma baru pembangunan Indonesia berbasis kelautan. Orasi Ilmia: Guru Besar Tetap Bidang Pengelolaan Sumberdaya Pesisir dan Lautan. Fakultas Perikanan dan IImu Kelautan-IPB, $233 \mathrm{hlm}$.

Dinas Kelautan dan Perikanan Pangkep. 2007. Laporan Akuntabilitas Kinerja Instansi
Pemerintah (LAKIP). Dinas Kelautan dan Perikanan, Pemerintah Kabupaten Pangkajene dan Kepulauan. 28 hal.

Effendi, H. 2000. Telaahan kualitas air bagi pengelolaan sumberdaya dan lingkungan perairan. Jurusan Manajemen Sumberdaya Perairan. Fakultas Perikanan dan IImu Kelautan, Institut Pertanian Bogor, Bogor, $259 \mathrm{hlm}$.

Hawkes. 1976. Principle standard methods for determining ecological criteria on hydrobiocoenose. Pergamon Press, Oxford, $176 \mathrm{pp}$.

Husaini, M. 2006. Rumput laut: pemanfaatan dan pemasarannya. Dalam Diseminasi Teknologi dan Temu Bisnis Rumput Laut, Makassar 11 September 2006. Badan Riset Kelautan dan Perikanan. Departemen Kelautan dan Perikanan, $35 \mathrm{hlm}$.

Mahfud, I. 2008. Laporan hasil kegiatan PRA Desa Mattiro Deceng (Pulau Badi dan Pulau Pajenekang), $12 \mathrm{hlm}$.

Mayunar, Purba, R., \& Imanto, P.T. 1995. Pemilihan lokasi untuk budidaya ikan laut. Prosiding Temu Usaha Pemasyarakatan Teknologi Keramba Jaring Apung Bagi Budidaya Laut. Pusat Penelitian dan Pengembangan Perikanan. Badan Penelitian dan Pengembangan PertanianFKPPA Agri-Business Club.

Nontji, A. 1986. Laut Nusantara. Djambatan, Jakarta.

Morain, S. 1999. GIS Solution in Natural Resource Management: Balancing the Technical-Political Equation. On Word Press. USA, $361 \mathrm{pp}$.

Mubarak, H., Ilyas, S., Ismail, W., Wahyuni, I.S., Hartati, S.H., Pratiwi, E., Jangkaru, Z., \& Arifuddin, R. 1990. Petunjuk teknis budidaya rumput laut. Pusat Penelitian dan Pengembangan Perikanan, PHP/KAN/PT/ 13/1990, Jakarta, 93 hlm.

Nurdjana, M.L. 2005. Iklim usaha yang kondusif bagi pengembangan akuakultur di Indonesia. Disampaikan pada acara Konferensi Nasional Akuakultur di Makassar, 23-25 November 2005. Kerja sama Masyarakat Akuakultur Indonesia, Balai Riset Perikanan Budidaya Air Payau dan Balai Besar Perikanan Budidaya Laut. Makassar, $25 \mathrm{hlm}$.

Odum, E.P. 1963. Ecology, Second Edition. Holt, Rinehart and Windston, Inc Allrights Reserve, $243 \mathrm{pp}$.

Odum, E.P. 1971. Fundamental Ecology $3^{\text {rd }}$. W. B Sanders Company. Phildelphia, 574 pp. 
Pong-Masak, P.R., Tjaronge, M., Suryati, E., \& Rachmansyah. 2006. Musim tanam rumput laut yang produktif di perairan Polewali Kabupaten Polman, Sulawesi Barat. Laporan Hasil Penelitian Balai Riset Perikanan Budidaya Air Payau TA. 2006. Maros, 18 hlm.

Pong-Masak, P.R. \& Hasnawi. 2007. Analisis Kesesuaian lahan untuk pengembangan budidaya rumput laut di perairan Polewali, Kabupaten Polman, Sulawesi Barat. Laporan Hasil Penelitian Balai Riset Perikanan Budidaya Air Payau TA. 2006. Maros, 13 hlm.

Pong-Masak, P.R., Tjaronge, M., Madeali, M.I., \& Suryati, E. 2008. Musim tanam rumput laut di Perairan Tonra, Kabupaten Bone, Pantai Timur Sulawesi Selatan. Makalah dipresentasikan pada Seminar Nasional INDOAQUA 2008, 17-20 Nov 2008. Jogjakarta, $14 \mathrm{hlm}$.

Pong-Masak, P.R., Madeali, M.I., \& Tjaronge, M. 2008. Musim tanam rumput laut di Perairan Pantai Selatan, Kabupaten Bantaeng, Pantai Selatan Sulawesi Selatan. Makalah dipresentasikan pada Seminar Nasional Masyarakat Akuakulture Indonesia 2008, April 2008. Lampung, $12 \mathrm{hlm}$.
Puja, Y., Sudjiharno, \& Aditya, T.W. 2001. Pemilihan Lokasi Budidaya. Dalam Teknologi Budidaya Rumput Laut, Kappaphicus allvarezii. Departemen Kelautan dan Perikanan, Direktorat Jenderal Perikanan Budidaya. Balai Budidaya Laut Lampung. Juknis Seri No. 8, hlm 13-17.

Radiarta, I N., Saputra, A., \& Priono, B. 2004. Pemetaan kelayakan lahan untuk pengembangan usaha budidaya laut di Teluk Saleh, Nusa Tenggara Barat. J. Pen. Perik. Indonesia, 10(5): 19-32.

Syaiful, M., Azhar, L.M., Razak, A., Wahidin, \& Arif. 2001. Penelitian potensi pengembangan kawasan budidaya perikanan dan kelautan Kabupaten Dompu. Laporan Kegiatan Kerjasama antara Bappeda dengan Dinas Perikanan dan Kelautan, $40 \mathrm{hlm}$.

Utojo, Mansyur, A., Pirzan, A.M., Tarunamulia, \& Pantjara, B. 2004. Identifikasi kelayakan lokasi lahan budidaya laut di perairan Teluk Saleh, Kabupaten Dompu Nusa Tenggara Barat. J. Pen. Bud. Pantai, 10(5): 1-18. 